\title{
THE GLOBAL PANDEMIC (COVID-19) HAS CAUSED LONG MEMORIES IN EUROPE'S BANKING SECTOR
}

\author{
Rui Dias ${ }^{1}$ \\ João M. Pereira ${ }^{2}$ \\ Luísa Cagica Carvalho ${ }^{3}$
}

Received: April 9, 2021 / Revised: October 5, 2021 / Accepted: October 27, 2021

(C) Association of Economists and Managers of the Balkans, 2021

\begin{abstract}
This study aims to analyze the impact of the 2020 global pandemic on the banking sectors of the countries of France, Germany, Greece, Ireland, Italy, Portugal, and Spain for the period from January 1, 2018, to August 10, 2020, with the sample being split into two subperiods: first subperiod from January 2018 to August 2019 (Pre-Covid); and the second from September 2019 to August 2020 (Covid-19). Different approaches were undertaken to perform this analysis, in order to verify whether: (i) the global pandemic (Covid-19) accentuated the persistence, in the returns, of the European banking sectors? (ii) the presence of long memories increases the synchronizations between markets? The main findings show that the assumption of the market efficiency hypothesis may be challenged, due to the possible predictability of the banking sectors' actions, and that the analyzed sectors also show marked levels of integration, thus questioning the hypothesis of efficient portfolio diversification. The results seem to be of interest to investors looking for opportunities in these specific sectors and for policymakers to carry out institutional reforms to increase efficiency and promote sustainable growth of financial markets.
\end{abstract}

Keywords: Covid-19, Banking sectors, Arbitrage, Portfolio diversification.

\section{JEL Classification C58 · G15}

rui.dias@esce.ips.pt

School of Business Administration at Polytechnic Institute of Setúbal, Portugal and CEFAGE-UE, IIFA, University of Évora, Portugal

University of Aberta, Portugal

Polytechnic Institute of Setubal, Portugal \& CEFAGE, University of Évora, Portugal 


\section{INTRODUCTION}

The European banking sector has been in the spotlight for the last ten years. There are several reasons for this: the impact of the global financial crisis on the stability of banks; the vulnerability of banking institutions to the Euro crisis and, last but not least, the problems of the largest banks in Italy and Germany, which in recent decades were considered the most efficient. The financial crisis has negatively impacted not only small national banks but also more robust international institutions demonstrating that the problem of measuring the efficiency of the banking sector is still a current and important issue for both academia, and international regulators (Allegret, Raymond, and Rharrabti, 2017; Dietrich and Vollmer, 2012; Flögel and Gärtner, 2020).

A market is held to be efficient when all relevant stock price information is reflected in the market price. The lack of consensus among economists and financial analysts on market efficiency implies that the efficient market hypothesis should be further studied. Another significant reason to study market efficiency is the role of stock markets acting as financial intermediaries, between savers and borrowers, in the distribution of scarce resources via price mechanisms (Jain, 2020; Karasiński, 2020).

The market efficiency hypothesis relates to the asset's current price reflecting all available information at a given time and the price adjusting rapidly as new and unanticipated information arrives in the market. The mean-reversion hypothesis, also called negative serial correlation, has been interpreted as an efficient correction mechanism in developed markets and a sign of a speculative bubble in emerging financial markets (Summers, 1986; Fama and French, 1988).

In corroboration, the rhoDCCA validates the results of the Detrended Fluctuation Analysis (DFA) exponent, showing 19 strong $(0.666 \rightarrow \cong 1.000)$ cross-correlation coefficients ( $\lambda$ _DCCA) (out of a possible 21 in total), with the exception made to the pairs France DS Banks / Germany DS Banks (0.12), Ireland DS Banks / Italy DS Banks (0.59). These findings show that the banking sectors analyzed evidenced marked levels of integration, which in return may question the hypothesis of efficient portfolio diversification.

This research contributes to the existing literature, namely the study of efficiency in its weak form in the banking sector within the global pandemic context (Covid-19). To our knowledge, other studies have analyzed banking sectors to examine whether they are efficient, in their weak form, by testing the possibility of investors obtaining abnormal returns without incurring additional risk. Some of these studies have been conducted by the authors Balcerzak, Kliestik, Streimikiene, and Smrčka (2017), Asaad (2017), AL-Hisnawi, Abd AL-Shara, and Al-Bidairi (2018), Aloui, Shahzad, and Jammazi (2018), Ferreira, Dionísio, Guedes, and Zebende (2018), Sharma (2018), Grmanová and Ivanová (2018), González, Razia, Búa, and Sestayo (2019), but with a different emphasis and focus of this study, namely regarding the analyzed markets, the sample period and the research questions.

In terms of structure, this paper is organized into five sections. The five sections pertain to an introduction, a literature review on market efficiency in its weak form, methods, results, and conclusions.

\section{LITERATURE REVIEW}

The issue of market efficiency has been addressed in different studies. These studies have analyzed the hypothesis of predictability of returns through the mean-reversion patterns of stock prices, inspired by the seminal work of Poterba and Summers (1988), Fama and French (1988), who have 
documented the mean reversion in stock markets over a time span longer than a year. According to the authors Malafeyev, Awasthi, S.Kambekar, and Kupinskaya (2019), when the random walk and informational efficiency hypotheses are rejected, extreme moves on stock prices can be observed. The occurrence of these phenomena may eventually decrease the implementation of efficient portfolio diversification strategies. Ascarya, Yumanita, Achsani, and Rokhimah (2008), Bashir, Ilyas, and Furrukh (2011), Tai (2011), Řepková (2014) examined the efficiency of banking sectors in several countries.

Ascarya, Yumanita, Achsani, and Rokhimah (2008) analyzed banks' efficiency in Malaysia and Indonesia. The authors evidenced that Malaysian banks have improved their efficiency and become as efficient as Indonesian banks were in 2006. On the other hand, Bashir, Ilyas, and Furrukh (2011) examined informational efficiency, in its weak form, in Pakistan's banking sector (KSE). The authors advocate that the random walk hypothesis is rejected, showing that the market sector shows signs of inefficiency. Furthermore, prices show predictable patterns in the KSE banking sector. Tai (2011) examined the UAE banking sector's efficiency based on a sample of UAE national banks. The authors show that large banks tend to be more efficient. Řepková (2014) studied the efficiency of commercial banks in the Czech Republic, the author provides evidence that large banks are less efficient than the other banks in this sector.

Narayan, Narayan, Popp, and Ali Ahmed (2015), Kok and Munir (2015), Sufian, Kamarudin, and Nassir (2016), Niţoi and Pochea (2016), Ching, Munir, and Bahron (2016), Apergis and Polemis (2016) tested whether bank stocks show signs of (in) efficiency. Narayan, Narayan, Popp, and Ali Ahmed (2015) analyzed firms belonging to the NYSE market's banking sector. These authors found significant evidence that the efficient market hypothesis depends on the day of the week, and that only $62 \%$ of firms show efficiency, in its weak form.

Kok and Munir (2015) studied the efficient market hypothesis in its weak form in the Malaysian stock market's banking sector. The authors evidenced that the data series follow the random walk hypothesis, implying that the financial sector is efficient, in its weak form. Sufian, Kamarudin, and Nassir (2016) analyzed the Malaysian banking sector's efficiency, suggesting that bank stocks increased their efficiency over the sample period. Niţoi and Pochea (2016) analyzed financial convergence between equity markets, sovereign CDS, long-term government bonds, and the banking sector from Central and Eastern Europe (CEEC). The authors demonstrated that CEE financial markets do not form a homogeneous convergence. Furthermore, in the aftermath of the global financial crisis and the sovereign debt crisis, the disparities between these financial markets increased. CEEs should implement further structural reforms in order to achieve greater financial convergence. Ching, Munir, and Bahron (2016) examined the market efficiency of Malaysian commercial banks in their weak form. The authors show and based on their results, that all series can be characterized by a random walk process, suggesting that the banks' actions are efficient, in their weak form. Apergis and Polemis (2016) examined the efficiency in the banking sector of the Middle East and North Africa (MENA) countries in the period 1997-2011 and have evidenced that the efficient market hypothesis is rejected.

Balcerzak, Kliestik, Streimikiene, and Smrčka (2017), Asaad (2017), AL-Hisnawi, Abd ALShara, and Al-Bidairi (2018), Aloui, Shahzad, and Jammazi (2018), Ferreira, Dionísio, Guedes, and Zebende (2018), Sharma (2018), Grmanová and Ivanová (2018), González, Razia, Búa, and Sestayo (2019) examined whether banking sectors are efficient, in their weak form, by testing whether investors can earn abnormal returns without incurring additional risk. Balcerzak, Kliestik, Streimikiene, and Smrčka (2017) highlight that there are differences between the efficiency 
of the banking sectors of the „old” fifteen and the „new” EU member countries. In corroboration, they show a clear difference between the efficiency of banking sectors that are members of the European Monetary Union and those that are not in the Eurozone. Asaad (2017) evidenced that bank stock prices on the Iraqi stock exchange do not reflect all historical information or, in other words, they are (in) efficient in their weak form and, thereby, create arbitrage opportunities.

Also, market efficiency levels vary over time, for both short and long-term periods, and change significantly in crisis and non-crisis scenarios. Ferreira, Dionísio, Guedes, and Zebende (2018) advocate that the financial crises of 2008 and 2010 affected European markets in general, and in particular the banking sector. Additionally, they also evidenced that the 63 European banks (inside and outside the Eurozone) analyzed decreased their market efficiency significantly. Sharma (2018) evidence a statistically significant association between operational efficiency and banking sector performance in India, i.e., operationally efficient banks create more value and profitability for investors and, therefore, are considered adequate.

Grmanová and Ivanová (2018) evidenced that the three largest Slovak banks are efficient in their weak form. González et al. (2019) analyzed 201 banks in the Middle East and North Africa (MENA) countries during 2005-2012. The authors mention that the efficiency hypothesis in the banking sector is rejected in MENA countries.

In summary, the contribution of this work is to provide information to investors and regulators in the European banking sectors, where individual and institutional investors seek diversification benefits, and to help promote the implementation of policies that contribute to the efficiency of these markets in this period of global pandemic (Covid-19).

\section{METHODOLOGY}

\subsection{Data}

The data used in this study comprised the price index (daily) of the banking sectors of France, Germany, Greece, Ireland, Italy, Portugal, and Spain, for the period from January 1, 2018, to August 10, 2020. The sample was split into two subperiods. The first subperiod is from January 2018 to August 2019 (Pre-Covid), and the second is from September 2019 to August 2020 (Covid-19). The information was obtained from the Thomson Reuters platform, with the quotes presented in local currency to mitigate exchange rate distortions.

Table 1. The countries and their indices used in the study.

\begin{tabular}{ll}
\hline Index & Country \\
\hline France DS Banks & France \\
\hline Germany DS Banks & Germany \\
\hline Greece DS Banks & Greece \\
\hline Ireland DS Banks & Ireland \\
\hline Italy DS Banks & Italy \\
\hline Portugal DS Banks & Portugal \\
\hline Spain DS Banks & Spain \\
\hline
\end{tabular}

Source: Own elaboration 


\subsection{Methods}

The research was conducted in several stages. The sample's characterization was done through descriptive statistics, using the test of adherence of Jarque and Bera (1980) to verify that the data followed a normal distribution. To verify the stability of variance, we performed plots of the residuals and used the test of Clemente et al. (1998) to identify the breaks in structure in the two sub-periods (Pre and during the Covid-19 period). Detrended Cross-Correlation Analysis ( $p D C C A$ ) methodology was applied to answer the research questions.

DFA is an analysis method that examines time dependence in nonstationary data series. This technique avoids spurious results when the analysis focuses on the data series's relationships in the long run by assuming that the time series are nonstationary. $D F A$ has the following interpretation: $0<\alpha<0,5$ : anti persistent series; $\alpha=0,5$ series exhibits random walk; $0,5<\alpha<1$ persistent series. This technique's function is to examine the relationship between $x_{k}$ and $x_{k+t}$ values at different times (Guedes et al., 2018).

The trend-free cross-correlation coefficient ( $p D C C A$ ) by Zebende (2011) is a method for quantifying the level of cross-correlation between two nonstationary time series. The coefficient is based on the DFA (Peng et al., 1994) and DCCA (Podobnik and Stanley, 2008) methods. The cross-correlation coefficient depends on the length of the s box (time scale). One of the advantages of this cross-correlation coefficient is centered on the possibility of measuring the correlations between two nonstationary time series on different time scales.This technique's function is to examine the relationship between $\mathrm{x}_{\mathrm{k}}$ and $\mathrm{x}_{\mathrm{k}+\mathrm{t}}$ values at different times (Ferreira,Dionísio,Guedes, and Zebende,2018). Tables 2 and 3 show the interpretation of the exponents $\alpha_{\mathrm{DFA}}$ and $p D C C A$

Table 2. Detrended Fluctuation Analysis $\alpha_{D F A}$

\begin{tabular}{cc}
\hline Exponent & Type of signal \\
\hline$\alpha_{\mathrm{DFA}}<0.5$ & long-range anti-persistent \\
\hline$\alpha_{\mathrm{DFA}} \simeq 0.5$ & uncorrelated, white noise \\
\hline$\alpha_{\mathrm{DFA}}>0.5$ & long-range persistent \\
\hline
\end{tabular}

Source: Own elaboration

Table 3. Detrended cross-correlation coefficient, $p D C C A$, levels

\begin{tabular}{ccc}
\hline Weak & Medium & Strong \\
\hline$\cong 0.000 \rightarrow \cong 0.333$ & $\cong 0.333 \rightarrow \cong 0.666$ & $\cong 0.666 \rightarrow \cong 1.000$ \\
\hline
\end{tabular}

Source: Own elaboration

\section{RESULTS AND DISCUSSION}

Figure 1 depicts the evolution of the banking sectors of the countries of France, Germany, Greece, Ireland, Italy, Portugal, and Spain, in levels, for the period from January 2, 2018, to August 10, 2020 , which is a period of considerable complexity since it comprises the outbreak of the global pandemic (Covid-19). Most markets show structure breaks in February and March 2020.

Figure 2 depicts the evolution, in \% differences, of the seven banking sectors under analysis. In all series, there is a relatively high dispersion around the average and a relatively synchronized behavior between the data series. Through the graphical analysis, one can observe high volatility, especially in January, February, and March 2020. 

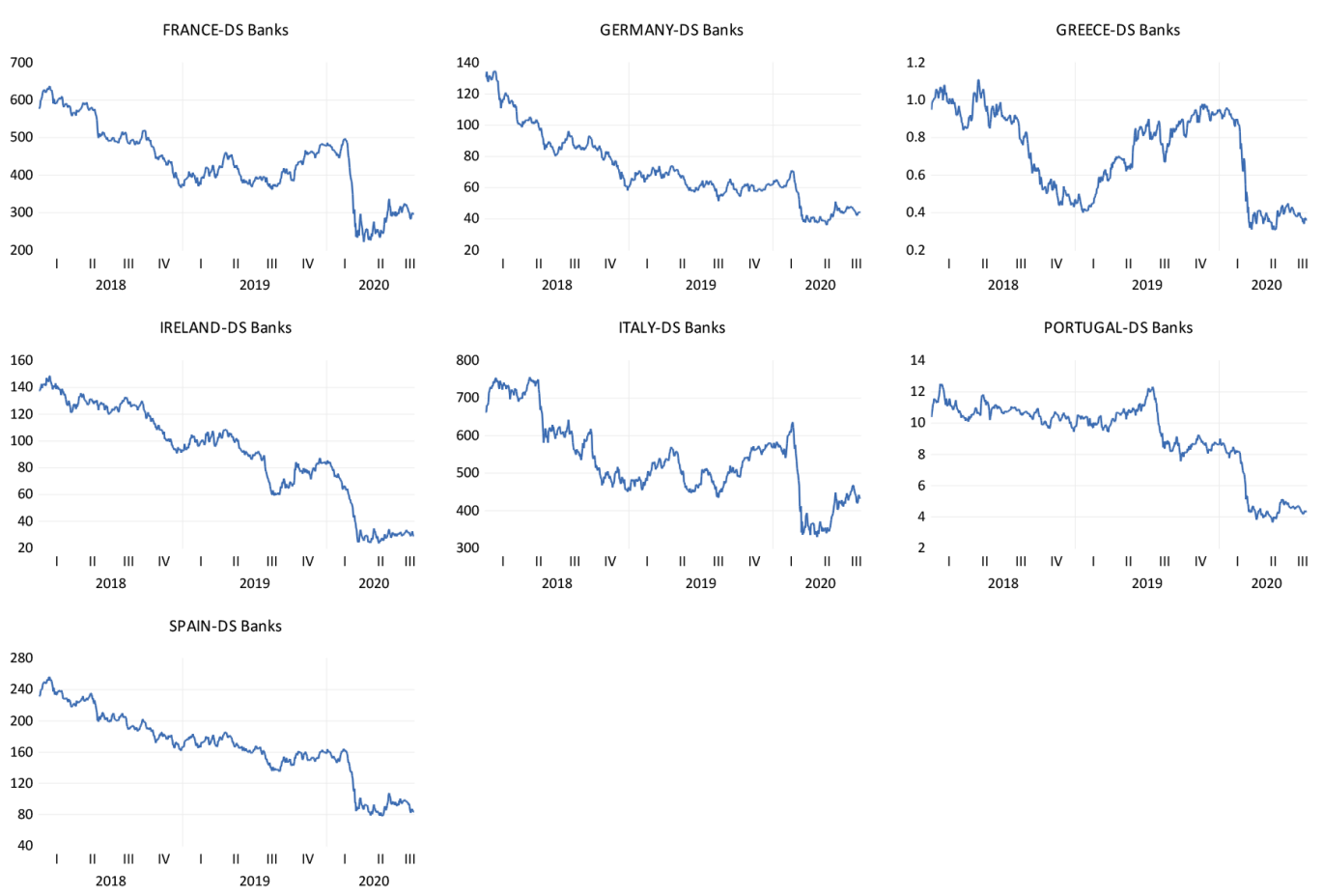

Figure 1. Evolution, in levels, of the seven banking sectors, in the period from $01 / 02 / 2018$ to $08 / 10 / 2020$

Source: Own elaboration

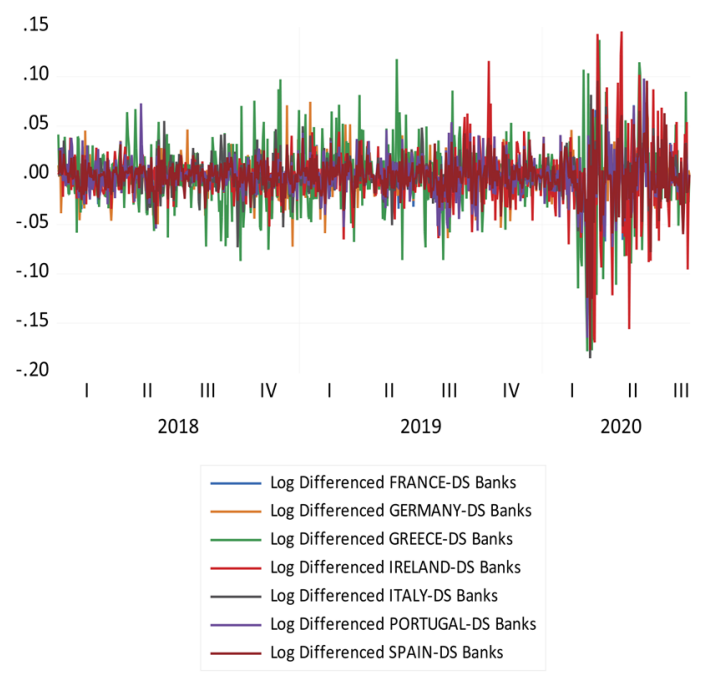

Figure 2. Evolution, in \% of differences, of the seven banking sectors, for the period from $01 / 02 / 2018$ to $08 / 10 / 2020$

Source: Own elaboration 

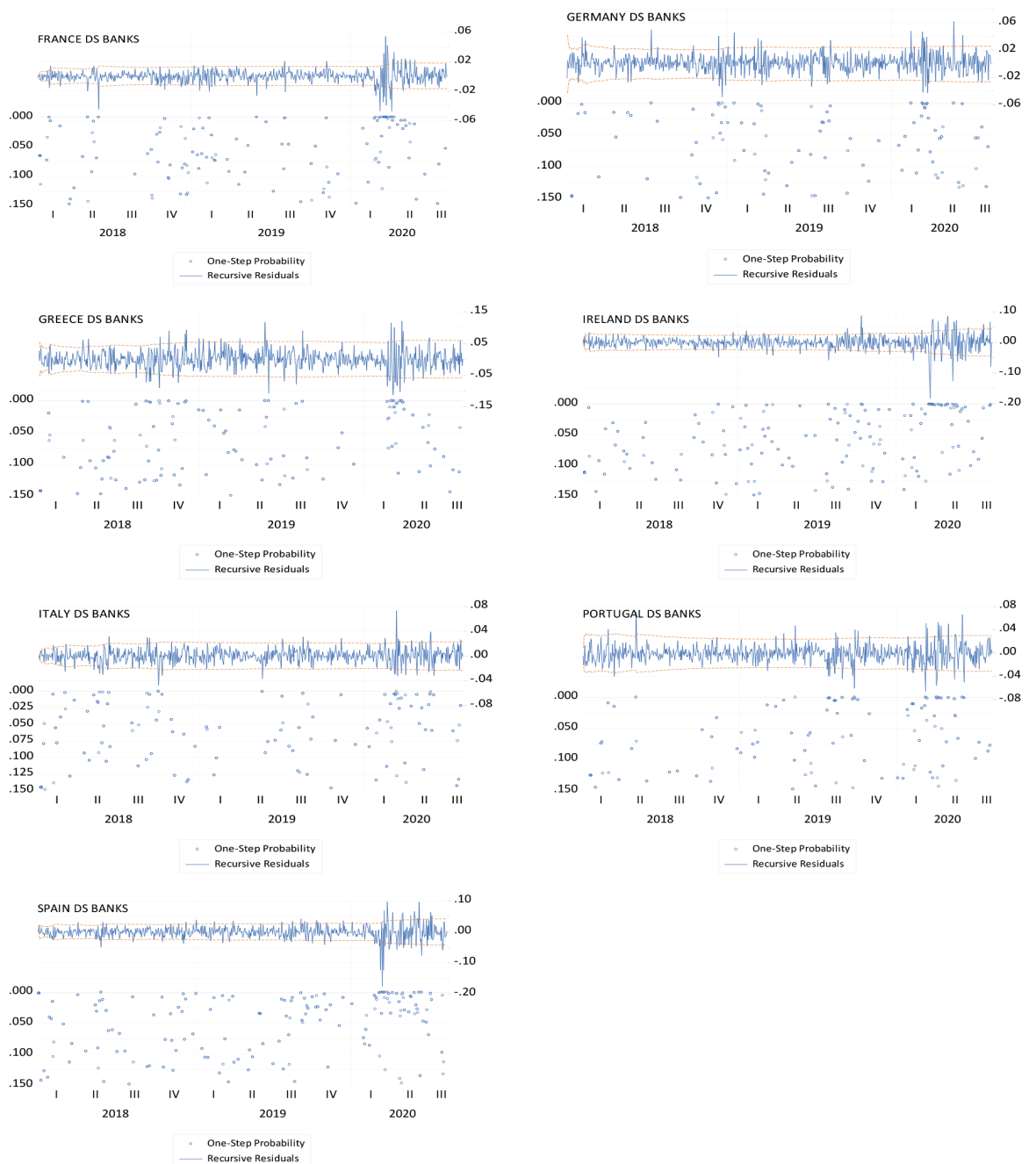

Figure 3. Stability tests performed on the residues of the seven banking sectors in the period from $02 / 01 / 2018$ to $10 / 08 / 2020$

\section{Source: Own elaboration}

Table 4 depicts the main descriptive statistics of the returns of the seven banking sectors under analysis. The returns show negative daily averages. The Greek banking sector has the highest standard deviation (0.034856), while the Italian banking sector has the highest kurtosis and asymmetry level. Also, the Jarque-Bera test confirms that we are dealing with time series that do not follow a normal distribution, evidence confirmed previously by the levels of skewness $(<0)$ and kurtosis (>3).

Figure 3 depicts the stability tests performed on the stock market residuals, measuring the existence of disturbances in the variance. Additionally, by examining the graphs and the $95 \%$ probability bounds, we observed a violation of the probability bounds, evidencing unstable behavior in the time series. 
Table 4. Descriptive statistics, in returns, of the 7 banking sectors, for the period $02 / 01 / 2018$ to $10 / 08 / 2020$

\begin{tabular}{|c|c|c|c|c|c|c|c|}
\hline & $\begin{array}{c}\text { FRANCE DS } \\
\text { BANKS }\end{array}$ & $\begin{array}{l}\text { GERMANY } \\
\text { DS BANKS }\end{array}$ & $\begin{array}{c}\text { GREECE } \\
\text { DS BANKS }\end{array}$ & $\begin{array}{l}\text { IRELAND } \\
\text { DS BANKS }\end{array}$ & $\begin{array}{c}\text { ITALY } \\
\text { DS BANKS }\end{array}$ & $\begin{array}{l}\text { PORTUGAL } \\
\text { DS BANKS }\end{array}$ & $\begin{array}{c}\text { SPAIN } \\
\text { DS BANKS } \\
\end{array}$ \\
\hline Mean & -0.000981 & -0.001587 & -0.001425 & -0.002280 & -0.000627 & -0.001285 & -0.001500 \\
\hline Std. Dev. & 0.022146 & 0.022170 & 0.034856 & 0.030538 & 0.020549 & 0.021192 & 0.021040 \\
\hline Skewness & -1.348067 & -0.540280 & -0.476581 & -0.422427 & -1.424886 & -0.831086 & -1.108491 \\
\hline Kurtosis & 14.58472 & 6.443499 & 7.116694 & 10.32545 & 15.60155 & 10.46002 & 14.69286 \\
\hline Jarque-Bera & $4014.348 * * *$ & $369.5928 * * *$ & $506.6551^{* * *}$ & $1542.920 * * *$ & $4736.361 * * *$ & $1657.519 * * *$ & $4018.978 * * *$ \\
\hline Sum & -0.667816 & -1.080719 & -0.970358 & -1.552853 & -0.426859 & -0.875276 & -1.021819 \\
\hline Sum Sq. Dev. & 0.333497 & 0.334239 & 0.826136 & 0.634131 & 0.287124 & 0.305396 & 0.301024 \\
\hline Observations & 681 & 681 & 681 & 681 & 681 & 681 & 681 \\
\hline
\end{tabular}

Note: ***.**. *. represent significance at $1 \% .5 \%$ and $10 \%$. respectively.

Source: Own elaboration.

Table 5 depicts the results of Clemente et al. (1998) unit root tests with structural breaks in the Pre-Covid subperiod, through which one can easily observe that the banking sectors mostly exhibit structure breaks in 2018, except for the banking sectors of Ireland and Portugal, which break in July 2019.

Table 5. Unit root tests with structural breaks of Clemente et al. (1998), in returns, referring to the seven banking sectors, in the period from 01/02/2018 to 08/30/2019

\begin{tabular}{lll}
\hline Index & t-stat & Break Date \\
\hline France DS Banks & $-19.81(0)^{* * * *}$ & $06 / 12 / 2018$ \\
\hline Germany DS Banks & $-22.24(0)^{* * *}$ & $20 / 12 / 2018$ \\
\hline Greece DS Banks & $-19.51(0)^{* * *}$ & $03 / 12 / 2018$ \\
\hline Ireland DS Banks & $-20.28(0)^{* * *}$ & $29 / 07 / 2019$ \\
\hline Italy DS Banks & $-20.09(0)^{* * *}$ & $28 / 09 / 2018$ \\
\hline Portugal DS Banks & $-20.89(0)^{* * *}$ & $16 / 07 / 2019$ \\
\hline Spain DS Banks & $-20.93(0)^{* * *}$ & $29 / 05 / 2018$ \\
\hline
\end{tabular}

Note: Lag Lenght (Automatic Length based on SIC).

Break Selection: Minimize Dickey-Fuller t-statistic. The lateral values in parentheses refer to lags. ***.**. *. represent significance at $1 \%$. 5\% and $10 \%$. respectively.

Source: Own elaboration

Table 6 depicts the unit root tests' results with structure breaks of Clemente et al. (1998) in the Covid subperiod. We can observe that the banking sectors show mostly structure breaks in March 2020, except for Italy's banking sector. The results are in line with G.Sudha and V.Sornaganesh (2020) findings, showing that the oil price war between Russia and Saudi Arabia, after an OPEC agreement was not reached, caused a significant drop in financial markets in March 2020.

Table 6. Unit root tests with structural breaks of Clemente et al. (1998), in returns, regarding the seven banking sectors, from 03/09/2019 to 10/08/2020.

\begin{tabular}{lll}
\hline Index & t-stat & Break Date \\
\hline France DS Banks & $-15.94(0)^{* * *}$ & $16 / 03 / 2020$ \\
\hline Germany DS Banks & $-15.49(0)^{* * *}$ & $12 / 03 / 2020$ \\
\hline Greece DS Banks & $-16.24(0)^{* * *}$ & $09 / 03 / 2020$ \\
\hline Ireland DS Banks & $-14.68(0)^{* * *}$ & $19 / 03 / 2020$ \\
\hline Italy DS Banks & $-17.11(0)^{* * *}$ & $13 / 09 / 2019$ \\
\hline Portugal DS Banks & $-16.09(0)^{* * *}$ & $09 / 03 / 2020$ \\
\hline Spain DS Banks & $-16.35(0)^{* * *}$ & $16 / 03 / 2020$ \\
\hline
\end{tabular}

Note: Lag Lenght (Automatic Length based on SIC).

Break Selection: Minimize Dickey-Fuller t-statistic. The lateral values in parentheses refer to lags. ***.**.*. represent significance at $1 \% .5 \%$ and $10 \%$. respectively.

Source: Own elaboration 

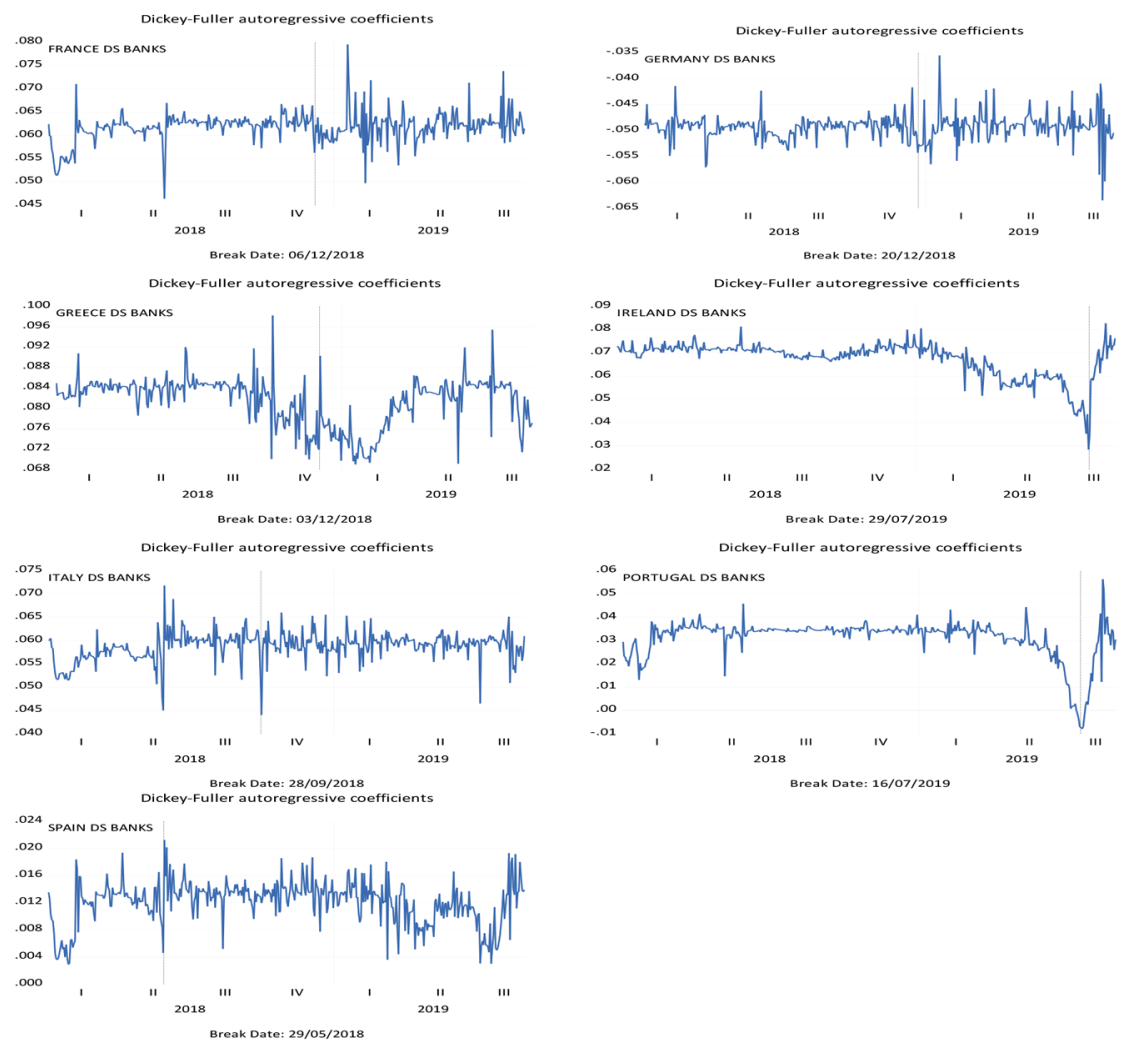

Figure 4. Graphical representation of the Clemente et al. (1998) structure breakdowns, in returns, pertaining to the seven banking sectors, from 02/01/2018 to 30/08/2019.

Source: Own elaboration

In Table 7, we can observe the DFA exponents for seven banking sectors in Europe. Period I comprises the Pre-Covid time scale and evidences the presence of long memories in France and Italy's banking sectors. In contrast, the remaining banking sectors present signs of equilibrium since the random walk hypothesis was not rejected. Period II encompasses the Covid-19 time scale, and the presence of significant long memories in all banking sectors under analysis was found, except in the banking sector of Ireland (0.49).

Table 7. DFA exponent for index and return.

The values of the linear adjustments for $\alpha$ DFA always had R2 $>0.99$.

\begin{tabular}{lcc}
\hline Stock market & DFA exponent (before the crisis) & DFA exponent (crisis period) \\
\hline France DS Banks & $0.55 \cong 0.0003$ & $0.60 \cong 0.0009$ \\
\hline Germany DS Banks & $0.52 \cong 0.0005$ & $0.63 \cong 0.0055$ \\
\hline Greece DS Banks & $0.49 \cong 0.0032$ & $0.57 \cong 0.0076$ \\
\hline Ireland DS Banks & $0.45 \cong 0.0019$ & $0.49 \cong 0.0066$ \\
\hline Italy DS Banks & $0.56 \cong 0.0034$ & $0.64 \cong 0.0042$ \\
\hline Portugal DS Banks & $0.48 \cong 0.0097$ & $0.61 \cong 0.0050$ \\
\hline Spain DS Banks & $0.49 \cong 0.0086$ & $0.57 \cong 0.0009$
\end{tabular}

Note: The hypotheses are $\mathrm{H}_{0}: \alpha=0.5$ and $\mathrm{H}_{1}: \alpha \neq 0.5$.

Source: Own elaboration. 
These findings show that the assumption of the market efficiency hypothesis may be questioned since the prediction of the market movement may be improved by considering the lagged movements of the other markets, thus allowing for arbitrage operations. These findings are in line with the evidence found in the work of Ferreira, Dionísio, Guedes, and Zebende (2018), González et al. (2019), showing that the banking sectors analyzed by these authors do not follow the efficient market hypothesis.
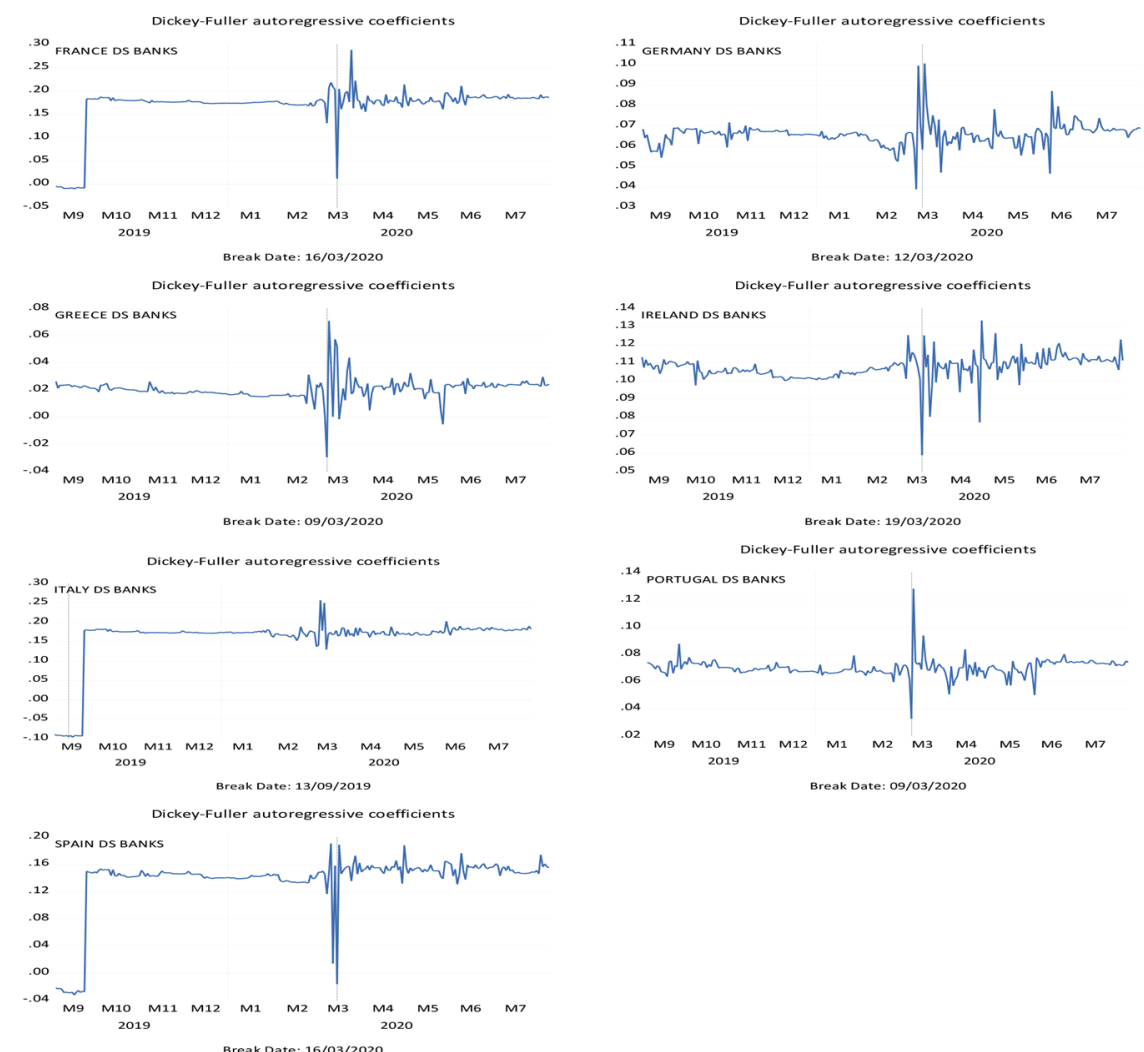

Figure 5. Graphical representation of the Clemente et al. (1998) structure breaks, in returns, regarding the seven banking sectors, in the period from 09/03/2019 to $08 / 10 / 2020$

\section{Source: Own elaboration}

In Table 8, we can observe the Detrended cross-correlation coefficient ) (out of 21 possible ones), with an exception made to the pairs France DS Banks / Germany DS Banks (0.12), Ireland DS Banks / Italy DS Banks (0.59). These findings show that the banking sectors analyzed show marked levels of integration, which may question the hypothesis of efficient portfolio diversification.

In Table 8, we can observe the Detrended cross-correlation coefficient pDCCA referring to the period from January 02,2018,to August 30,2019,encompassing both the Pre-Covid subperiod and the one during Covid-19.The banking sectors show that the $p D C C A$ increased significantly during the Covid-19 period,except for the pair France DS Banks / Germany DS Banks which decreased. The banking sectors under analysis show that during Covid-19, there are 19 strong $(0.666 \rightarrow \cong$ 1.000 ) cross-correlation coefficients ( $\lambda$ _DCCA) (out of 21 possible ones), with an exception made to the pairs France DS Banks / Germany DS Banks (0.12), Ireland DS Banks / Italy DS Banks (0.59). These findings show that the banking sectors analyzed show marked levels of integration, which may question the hypothesis of efficient portfolio diversification. 
Table 8. Summary of the $p D C C A$ coefficients, referring to the banking sector, for the period from $02 / 01 / 2018$ to $10 / 08 / 2020$

\begin{tabular}{|c|c|c|c|c|c|}
\hline & & & & & \multirow{3}{*}{ Tendency } \\
\hline & \multicolumn{2}{|c|}{$p D C C A$ (before Covid-19) } & \multicolumn{2}{|c|}{$p D C C A$ (Covid-19) } & \\
\hline \multirow{2}{*}{$\begin{array}{l}\text { Index } \\
\text { France DS Banks / } \\
\text { Germany DS Banks }\end{array}$} & \multicolumn{2}{|c|}{$p D C C A$ Time scale (days) } & \multicolumn{2}{|c|}{$p D C C A$ Time scale (days) } & \\
\hline & 0.87 & $\mathrm{n}>63$ days & 0.12 & $\mathrm{n}>11$ days & $\downarrow$ \\
\hline $\begin{array}{l}\text { France DS Banks / } \\
\text { Greece DS Banks }\end{array}$ & 0.28 & $\mathrm{n}>20$ days & 0.80 & $\mathrm{n}>43$ days & $\uparrow$ \\
\hline $\begin{array}{l}\text { France DS Banks / } \\
\text { Ireland DS Banks }\end{array}$ & 0.65 & $\mathrm{n}>92$ days & 0.75 & $\mathrm{n}>52$ days & $\uparrow$ \\
\hline $\begin{array}{l}\text { France DS Banks / } \\
\text { Italy DS Banks }\end{array}$ & 0.76 & $\mathrm{n}>76$ days & 0.94 & $\mathrm{n}>35$ days & $\uparrow$ \\
\hline $\begin{array}{l}\text { France DS Banks / } \\
\text { Portugal DS Banks }\end{array}$ & 0.59 & $\mathrm{n}>35$ days & 0.89 & $\mathrm{n}>43$ days & $\uparrow$ \\
\hline $\begin{array}{l}\text { France DS Banks / } \\
\text { Spain DS Banks }\end{array}$ & 0.87 & $\mathrm{n}>35$ days & 0.94 & $\mathrm{n}>43$ days & $\uparrow$ \\
\hline $\begin{array}{l}\text { Germany DS Banks / } \\
\text { Greece DS Banks }\end{array}$ & 0.25 & $\mathrm{n}>29$ days & 0.78 & $\mathrm{n}>43$ days & $\uparrow$ \\
\hline $\begin{array}{l}\text { Germany DS Banks / } \\
\text { Ireland DS Banks }\end{array}$ & 0.67 & $\mathrm{n}>63$ days & 0.74 & $\mathrm{n}>52$ days & $\uparrow$ \\
\hline $\begin{array}{l}\text { Germany DS Banks / } \\
\text { Italy DS Banks }\end{array}$ & 0.70 & $n>43$ days & 0.91 & $\mathrm{n}>43$ days & $\uparrow$ \\
\hline $\begin{array}{l}\text { Germany DS Banks / } \\
\text { Portugal DS Banks }\end{array}$ & 0.62 & $\mathrm{n}>43$ days & 0.87 & $\mathrm{n}>43$ days & $\uparrow$ \\
\hline $\begin{array}{l}\text { Germany DS Banks / } \\
\text { Spain DS Banks }\end{array}$ & 0.82 & $\mathrm{n}>52$ days & 0.93 & $\mathrm{n}>35$ days & $\uparrow$ \\
\hline $\begin{array}{l}\text { Greece DS Banks / } \\
\text { Ireland DS Banks }\end{array}$ & 0.19 & $\mathrm{n}>76$ days & 0.69 & $\mathrm{n}>52$ days & $\uparrow$ \\
\hline $\begin{array}{l}\text { Greece DS Banks / } \\
\text { Italy DS Banks }\end{array}$ & 0.34 & $\mathrm{n}>92$ days & 0.82 & $\mathrm{n}>52$ days & $\uparrow$ \\
\hline $\begin{array}{l}\text { Greece DS Banks / } \\
\text { Portugal DS Banks } \\
\end{array}$ & 0.33 & $\mathrm{n}>76$ days & 0.83 & $\mathrm{n}>52$ days & $\uparrow$ \\
\hline $\begin{array}{l}\text { Greece DS Banks / } \\
\text { Spain DS Banks }\end{array}$ & 0.29 & $\mathrm{n}>35$ days & 0.81 & $\mathrm{n}>52$ days & $\uparrow$ \\
\hline $\begin{array}{l}\text { Ireland DS Banks / } \\
\text { Italy DS Banks }\end{array}$ & 0.51 & $\mathrm{n}>52$ days & 0.59 & $\mathrm{n}>35$ days & $\uparrow$ \\
\hline $\begin{array}{l}\text { Ireland DS Banks / } \\
\text { Portugal DS Banks }\end{array}$ & 0.61 & $\mathrm{n}>52$ days & 0.68 & $\mathrm{n}>43$ days & $\uparrow$ \\
\hline $\begin{array}{l}\text { Ireland DS Banks / } \\
\text { Spain DS Banks }\end{array}$ & 0.65 & $\mathrm{n}>63$ days & 0.73 & $\mathrm{n}>43$ days & $\uparrow$ \\
\hline $\begin{array}{l}\text { Italy DS Banks / } \\
\text { Portugal DS Banks }\end{array}$ & 0.61 & $\mathrm{n}>43$ days & 0.89 & $\mathrm{n}>52$ days & $\uparrow$ \\
\hline $\begin{array}{l}\text { Italy DS Banks / } \\
\text { Spain DS Banks }\end{array}$ & 0.79 & $\mathrm{n}>52$ days & 0.93 & $\mathrm{n}>43$ days & $\uparrow$ \\
\hline $\begin{array}{l}\text { Portugal DS Banks / } \\
\text { Spain DS Banks }\end{array}$ & 0.71 & $\mathrm{n}>43$ days & 0.87 & $\mathrm{n}>63$ days & $\uparrow$ \\
\hline
\end{tabular}

Source: Own elaboration

\section{CONCLUSION}

This study has analyzed the impact of the 2020 global pandemic on the banking sectors of the countries of France, Germany, Greece, Ireland, Italy, Portugal, and Spain for the period January 1, 2018, to August 10, 2020. The sample was split into two subperiods. The first subperiod is from January 2018 to August 2019 (Pre-Covid), and the second is from September 2019 to August 2020 
(Covid-19). The analysis involved different approaches to verify whether: (i) the global pandemic (Covid-19) stressed the persistence, in the returns, of the European banking sectors; (ii) the presence of long memories increases the synchronizations between markets.

To answer the underlying research questions in our study we employed the Detrended Fluctuation Analysis (DFA) and Detrended Cross-Correlation Analysis ( $p D C C A$ ) methodology. DFA is an analysis method that examines time dependence in nonstationary data series. The $p D C C A$, on the other hand, is a method for quantifying the level of cross-correlation between two nonstationary time series.

Our first test estimated the DFA exponents for seven banking sectors in Europe during two periods. Period I pertains to the Pre-Covid time scale, indicating the presence of long memories in France and Italy's banking sectors. In contrast, the remaining banking sectors show signs of equilibrium since the random walk hypothesis was not rejected. Finally, period II involves the Covid-19 time scale, and the presence of significant long memories in all banking sectors under analysis can be found, except in the case of the banking sector of Ireland (0.49). These findings show that the assumption of the market efficiency hypothesis may be questioned since the prediction of the market movement may be improved if the lagged movements of the other markets are considered, allowing for the occurrence of arbitrage operations. The second test estimated the Detrended cross-correlation coefficient pDCCA from January 02, 2018, to August 30, 2019, including both the Pre-Covid subperiod and the one during Covid-19. The banking sectors increased significantly during the Covid-19 period, except for France DS Banks / Germany DS Banks pair, which decreased.

The banking sectors under analysis show that, during Covid-19, there are 19 strong $(0.666 \rightarrow \cong$ 1.000 ) cross-correlation coefficients ( $\lambda$ _DCCA) (out of 21 possible ones), with an exception made to the pairs France DS Banks / Germany DS Banks (0.12), Ireland DS Banks / Italy DS Banks (0.59). These findings suggest that the analyzed banking sectors show marked levels of integration, which in return questions the hypothesis of efficient portfolio diversification.

As for the first research question raised in our study, the DFA results confirm that European banking sectors present signs of (in)efficiency in its weak form. These findings may have implications for investors, as some returns can be expected and are bound to create opportunities for arbitrage and abnormal profits. Regarding the second question, the fact that the rhoDCCA increased significantly in the Covid-19 period shows that autocorrelation across markets may question the hypothesis of portfolio diversification.

Finally, as a general conclusion supported by the results obtained through the tests using econophysics models, there is evidence that the global pandemic has a significant impact on the analyzed financial markets adjustment. The results of the study also suggest that these markets show significant persistence during the Covid period, causing in return arbitrage opportunities. Additionally, the increase in Detrended cross-correlation coefficient pDCCA observed in the Covid period, compared to the preceding subperiod, may suggest that portfolio diversification is difficult to attain under these circumstances. These findings also draw the attention of market regulators to take steps to ensure better information across international financial markets. In conclusion, investors should diversify their portfolios and invest in less risky markets to mitigate risk and improve their portfolios' efficiency. 


\section{REFERENCES}

AL-Hisnawi, S. S. R., Abd AL-Shara, A. S., \& Al-Bidairi, K. H. A. (2018). Testing the random movement of shares in the supply chain of some sectors listed in the Iraq stock exchange. International Journal of Supply Chain Management.

Allegret, J. P., Raymond, H., \& Rharrabti, H. (2017). The impact of the European sovereign debt crisis on banks stocks. Some evidence of shift contagion in Europe. Journal of Banking and Finance, 74, 24-37. https://doi.org/10.1016/j.jbankfin.2016.10.004

Aloui, C., Shahzad, S. J. H., \& Jammazi, R. (2018). Dynamic efficiency of European credit sectors: A rolling-window multifractal detrended fluctuation analysis. Physica A: Statistical Mechanics and Its Applications. https://doi.org/10.1016/j.physa.2018.04.039

Apergis, N., \& Polemis, M. L. (2016). Competition and efficiency in the MENA banking region: a non-structural DEA approach. Applied Economics. https://doi.org/10.1080/00036846.2016.11 76112

Asaad, Z. (2017). Testing the Bank Sector at Weak Form Efficiency in Iraq Stock Exchange for Period (2000-2014). SSRN Electronic Journal. https://doi.org/10.2139/ssrn.3069561

Ascarya, Yumanita, D., Achsani, N. A., \& Rokhimah, G. S. (2008). Measuring The Efficiency of Islamic Bank in Indonesia and Malaysia Using Parametric and Nonparametric Approach. In 3rd International Conference on Islamic Banking and Finance.

Balcerzak, A. P., Kliestik, T., Streimikiene, D., \& Smrčka, L. (2017). Non-parametric approach to measuring the efficiency of banking sectors in European union countries. Acta Polytechnica Hungarica. https://doi.org/10.12700/APH.14.7.2017.7.4

Bashir, T., Ilyas, M., \& Furrukh, A. (2011). Testing the weak-form efficiency of Pakistani stock markets -An empirical study in banking sector. European Journal of Economics, Finance and Administrative Sciences.

Ching, K. S., Munir, Q., \& Bahron, A. (2016). Malaysian banking sector efficiency, structural breaks and cross-sectional dependence: Empirical evidence. Journal of Economic Cooperation and Development.

Clemente, J., Montañés, A., \& Reyes, M. (1998). Testing for a unit root in variables with a double change in the mean. Economics Letters, 59(2), 175-182. https://doi.org/10.1016/S01651765(98)00052-4

Dietrich, D., \& Vollmer, U. (2012). Are universal banks bad for financial stability? Germany during the world financial crisis. Quarterly Review of Economics and Finance, 52(2), 123-134. https://doi.org/10.1016/j.qref.2011.12.008

Fama, E. F., \& French, K. R. (1988). Dividend yields and expected stock returns. Journal of Financial Economics. https://doi.org/10.1016/0304-405X(88)90020-7

Ferreira, P., Dionísio, A., Guedes, E. F., \& Zebende, G. F. (2018). A sliding windows approach to analyse the evolution of bank shares in the European Union. Physica A: Statistical Mechanics and Its Applications, 490, 1355-1367. https://doi.org/10.1016/j.physa.2017.08.095

Flögel, F., \& Gärtner, S. (2020). The COVID-19 Pandemic and Relationship Banking in Germany: Will Regional Banks Cushion an Economic Decline or is A Banking Crisis Looming? Tijdschrift Voor Economische En Sociale Geografie. https://doi.org/10.1111/tesg.12440

G.Sudha, V.Sornaganesh, M. T. S. (2020). IMPACT OF INDIAN STOCK MARKET DUE TO CRISIS IN MARCH 2020. International Journal of Multidisciplinary Educational Research.

González, L. O., Razia, A., Búa, M. V., \& Sestayo, R. L. (2019). Market structure, performance, and efficiency: Evidence from the MENA banking sector. International Review of Economics and Finance. https://doi.org/10.1016/j.iref.2019.05.013

Grmanová, E., \& Ivanová, E. (2018). Efficiency of banks in Slovakia: Measuring by DEA models. Journal of International Studies. https://doi.org/10.14254/2071-8330.2018/11-1/20 
Guedes, E. F., Brito, A. A., Oliveira Filho, F. M., Fernandez, B. F., de Castro, A. P. N., da Silva Filho, A. M., \& Zebende, G. F. (2018). Statistical test for $\triangle \rho D C C A$ : Methods and data. Data in Brief. https://doi.org/10.1016/j.dib.2018.03.080

Jain, E. (2020). Empirically testing weak form efficiency of Indian stock market: Pre and post demonetization. International Journal of Scientific and Technology Research.

Jarque, C. M., \& Bera, A. K. (1980). Efficient tests for normality, homoscedasticity and serial independence of regression residuals. Economics Letters, 6(3), 255-259. https://doi. org/10.1016/0165-1765(80)90024-5

Karasiński, J. (2020). The Changing Efficiency of the European Stock Markets. Annales Universitatis Mariae Curie-Skłodowska, Sectio H-Oeconomia. https://doi.org/10.17951/h.2020.54.1.41-51

Kok, S. C., \& Munir, Q. (2015). Malaysian finance sector weak-form efficiency: Heterogeneity, structural breaks, and cross-sectional dependence. Journal of Economics, Finance and Administrative Science. https://doi.org/10.1016/j.jefas.2015.10.002

Lawrence H. Summers. (1986). Does the stock market rationally reflect fundamental values. The Journal of Finance. https://doi.org/10.2307/2328487

Malafeyev, O., Awasthi, A., S.Kambekar, K., \& Kupinskaya, A. (2019). Random Walks and Market Efficiency in Chinese and Indian Equity Markets. Statistics, Optimization \& Information Computing. https://doi.org/10.19139/soic.v7i1.499

Narayan, P. K., Narayan, S., Popp, S., \& Ali Ahmed, H. (2015). Is the efficient market hypothesis day-of-the-week dependent? Evidence from the banking sector. Applied Economics. https:// doi.org/10.1080/00036846.2015.1005828

Niţoi, M., \& Pochea, M. M. (2016). Testing financial markets convergence in Central and Eastern Europe: A non-linear single factor model. Economic Systems. https://oi.org/10.1016/j.ecosys.2016.02.002

Peng, C. K., Buldyrev, S. V., Havlin, S., Simons, M., Stanley, H. E., \& Goldberger, A. L. (1994). Mosaic organization of DNA nucleotides. Physical Review E, 49(2), 1685-1689. https://doi. org/10.1103/PhysRevE.49.1685

Podobnik, B., \& Stanley, H. E. (2008). Detrended cross-correlation analysis: A new method for analyzing two nonstationary time series. Physical Review Letters, 100(8). https://doi.org/10.1103/ PhysRevLett.100.084102

Poterba, J. M., \& Summers, L. H. (1988). Mean reversion in stock prices. Evidence and Implications. Journal of Financial Economics. https://doi.org/10.1016/0304-405X(88)90021-9

Řepková, I. (2014). Efficiency of the Czech Banking Sector Employing the DEA Window Analysis Approach. Procedia Economics and Finance. https://doi.org/10.1016/s2212-5671(14)00383-9

Sharma, D. (2018). Stock Market Performance and Efficiency of Banks in a Developing Economy: Evidence from the Indian Banking Sector. IIM Kozhikode Society \& Management Review. https://doi.org/10.1177/2277975218770502

Sufian, F., Kamarudin, F., \& Nassir, A. md. (2016). Determinants of efficiency in the Malaysian banking sector: Does bank origins matter? Intellectual Economics. https://doi.org/10.1016/j. intele.2016.04.002

Tai, L. (2011). Competition and Efficiency of UAE Commercial Banks. Proceedings of the Northeast Business \& Economics Association. https://doi.org/10.1111/j.1467-9701.2008.01130.x

Zebende, G. F. (2011). DCCA cross-correlation coefficient: Quantifying level of cross-correlation. Physica A: Statistical Mechanics and Its Applications, 390(4), 614-618. https://doi. org/10.1016/j.physa.2010.10.022 